Article

\title{
Ibero-American Research on Local Development. An Analysis of Its Evolution and New Trends
}

\author{
José Luis Ruiz-Real ${ }^{1, * \mathbb{D}}$, Juan Uribe-Toril ${ }^{1}{ }^{\mathbb{C}}$, Jaime De Pablo Valenciano ${ }^{1}$ and \\ José Ramos Pires Manso ${ }^{2}$ \\ 1 Faculty of Economics and Business, University of Almeria, Ctra. De Sacramento, s/n, 04120 Almería, Spain \\ 2 Department of Management and Economics, Universidade da Beira Interior, R. Marquês de Ávila e Bolama, \\ 6201-001 Covilhã, Portugal \\ * Correspondence: jlruizreal@ual.es
}

Received: 16 June 2019; Accepted: 8 July 2019; Published: 10 July 2019

\begin{abstract}
Local development is a subject that arouses significant interest in the international scientific community in general, and in the Ibero-American one, in particular. The process of globalization has transformed the management of local development, altering the role that is played by local and regional entities, and it is the object of an important follow-up and analysis by academia. This research uses a bibliometric methodology and a fractional counting method, reviewing the 738 articles from the Scopus database in order to understand the state of Ibero-American research on local development, and analyze the scientific literature on the topic. The results show a significant increase in the number of publications in the 21st century, with Spain and Brazil leading the way. In addition, this research provides interesting results regarding the most influential authors on this topic, the most relevant journals, and the most important institutions and funding organizations. There are several areas of knowledge involved since local development is a transversal field, such as Social Science, environment, business, economics, and agriculture. A deep analysis of authors' keywords identified new trends, linking local development with tourism, education, geotourism, climate change, local sustainable development, social innovation, and creativity, which provides academia with potential new lines of research.
\end{abstract}

Keywords: Ibero-America; local development; sustainability; bibliometrics; Scopus; cross world research

\section{Introduction}

When considering local development, it is important to not only include an array of connected economic characteristics that influence the economic prosperity of a particular area [1], but also a series of geophysical, social, and economic factors that together create a "breeding ground", which results in activities that permit local areas to grow and flourish.

Four elements must be combined: basic infrastructure in order to understand local development, particularly telecommunications; active promotion of the area by local governments; natural resources, which can be exploited without damaging or undermining the environment; and, finally, an active and conscientious local population. Thus, development strategies should take into account both the economic and non-economic aspects (with greater importance given to less developed areas) and should be combined in order to obtain the best results [2,3].

The development of these processes in a local or specific area as the best strategy for sponsoring growth ultimately justifies the relevance of local development. The fact that development processes in similar environments can produce vastly different outcomes is proof of the difficulty in finding a common set of activities or processes that sponsor local economic growth [4]. What is more, economic growth in non-developed areas could, at first, be successful at the local level, whilst, at the same time, 
it does not result in sustainable growth in the long run for that same local area. Both the functional and specific types of processes converge into a more integral concept of local area development [5], in which this type of development is not just a coincidental factor in the economic growth of an area, but rather an essential element in development processes.

Various theories have been put forward in an attempt to explain the reasons why certain fundamental principles that influence economic growth and development in a specific local area, region, or country are successful or not. The theory of modernization was initially developed by Colin Clark [6] and Allan Fisher [7], involving the growth of income per capita, distribution of employment among the primary, secondary, and tertiary industries, processes of industrialization, and outsourcing services. The theory focuses on the internal relations of an economy and it pays less attention to exterior relationships. The concept of growth poles, as conceived by Perroux [8], states that growth does not appear out of nowhere or all at once; rather, at certain points or "poles", with varying degrees of intensity and it is propagated by means of diverse channels [9].

Krugman [10] points out that the concentration of economic development in certain areas of a country is the result of interactions between increasing returns, transport costs, and demand. In particular, this author sustains that each firm will choose to supply the national market from a single location if the economies of scale are sufficiently adequate. For Krugman, the renewed interest in geographic location constitutes the fourth and, perhaps, the last wave in the revolution of increasing returns and imperfect competition.

Local development and its intrinsic endogenous character, as understood by the Chilean professor, Sergio Boiser [11] has a triple meaning. It includes the capacity of a local area to save and invest the profits of economic production in the said same area, and thus promote more diverse development, as measured in terms of applied technology, the capacity to develop its own local strategy, and the ability to carry out the necessary procedures to achieve the goals that society has set itself and the existence of a local area's own unique culture and identity. Academics, such as Professor Gioacchino Garofoli [12-15], point out that local and endogenous development encompasses the capacity to transform a socioeconomic system; the ability to react to external challenges; the promotion of social learning; and, the ability to introduce particular forms of social regulation at a local level, which promotes the development of the growth previously described, that is, the ability to innovate at the local level.

Geographic Economics has made a study of the economic aspects in relation to factors, such as the natural and social environment, the causes of economic development, and its spatial distribution and development over time. For this reason, and as will consequently explained, many of the articles and studies regarding local development are published in journals focused on geographic matters. The local context contributes towards the socioeconomic dynamism, and given the logic of global networks, local areas can comport themselves in certain environments as either winners or emergents in local systems of production, industrial areas, and innovative methods [16,17]. However, this dynamism does not prevent the emergence of serious contradictions and problems, both of an environmental or territorial nature. The neoclassic theory of economics favors a balanced growth that is exogenously determined when considering the process of convergence in various countries. In contrast, the theory of endogenous economic growth states that the level of income per capita can enjoy limitless growth depending on the level of investment in technological research.

It is important to understand other aspects, such as the application of new technologies, the existence of a qualified labor force, and the stability of extant governments in order to understand the different forms of economic organization and the exploitation of the resources in different regions and countries around the world, in addition to the geographic factors. The Inter-American Development Bank [18] has empirically measured the relationship between physical geography (including the impact of natural phenomena) and economic development in Latin America. Some analysts have even suggested that there is a type of "curse" that is caused by the availability of natural resources in certain locations, which, according to them, these two factors are inversely related with development and the distribution of wealth in these countries. 
The principal objectives of this study are to analyze, on the one hand, the evolution of the concept of local development in the scientific production in Ibero-America and, on the other hand, discover new trends, what constitutes a contribution, since it allows for the Academy to have clear information regarding the most relevant potential future research lines.

This study has followed the criteria set out by the Ibero-American Secretary General and it has included the 22 countries that make up the Ibero-American community, that is, Andorra, Argentina, Bolivia, Brazil, Chile, Colombia, Costa Rica, Cuba, Dominican Republic, Ecuador, El Salvador, Guatemala, Honduras, Mexico, Nicaragua, Panama, Paraguay, Peru, Portugal, Spain, Uruguay, and Venezuela.

\section{Method}

A bibliometric analysis has been carried out in order to comprehend the influence of Ibero-American scientific production on the issue of local development. This type of analysis, whose origin can be found in the work by Gardfield [19], has been successfully used in recent decades. Bibliometric studies can be found, which focus on different topics [20-23], on specific publications [24,25] or on specific geographic regions [26-28]. The success of this methodology resides in the possibility of reflecting, in a quick and concise manner, the evolution and antecedents of a given topic, and, in addition, can also analyze trends and future lines of research based on the level of scientific production.

The principal databases containing indexes of scientific production are the Web of Science (WoS) and Scopus. Whilst WoS was the first database collection to index academic journals and a pioneer in the measurement of the impact of these journals, Scopus is becoming increasingly important and it has become a relevant database given the number of publications that are contained within its collection $[29,30]$. An initial analysis of these databases determined that the most adequate database for this work to be Scopus, as it contained a larger number of publications and registered works on the issue of local development than WoS. The analysis also used the software program, VOSviewer [31] to collate and visualize the extracted data in cluster maps, in addition to this database. Scientific rigor is assured with the application of systematic bibliometric analysis [32,33], which observed five sequential steps, as shown in Figure 1.

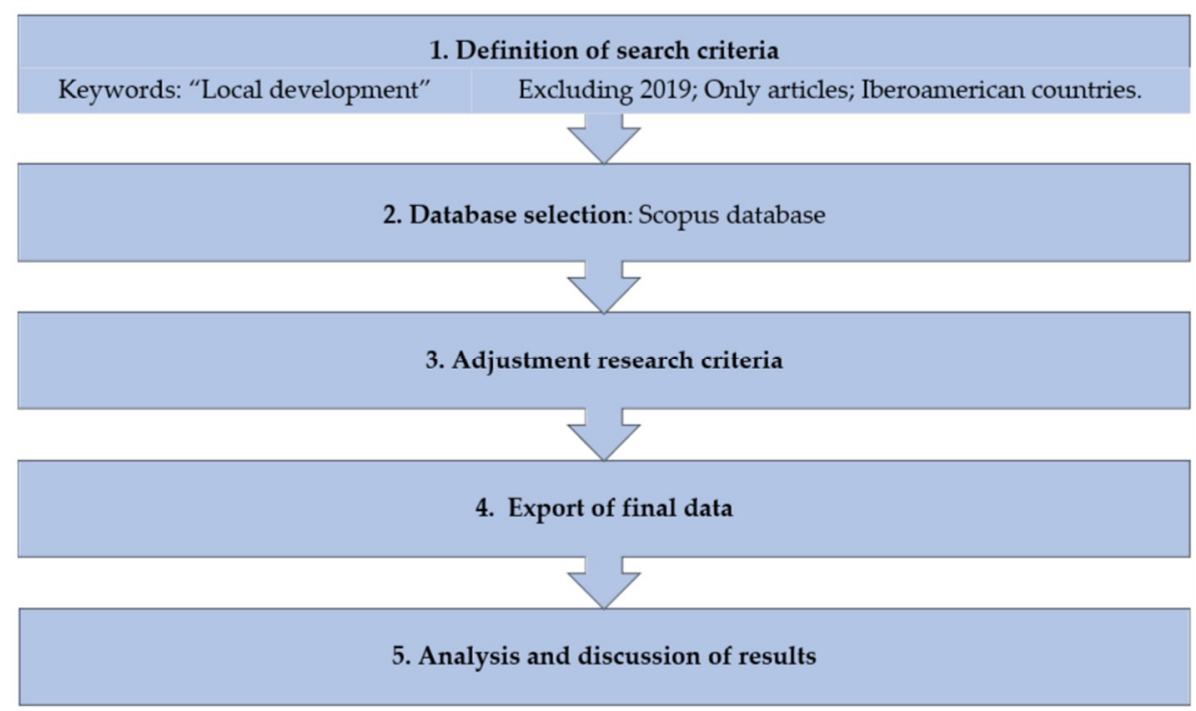

Figure 1. Methodology of bibliometric analysis.

The search queries were entered into the databases while using the terms "local development" within the title, abstract, or keywords. Over 5000 registered works were found in Scopus and 4400 in WoS. The search was further refined to exclude articles published in 2019 (as said year had not finished at the time of the research), to include only articles that were published in scientific journals in order to guarantee scientific rigor, and finally, to limit the search to include only Ibero-American 
articles. Following an initial analysis of the results, it was decided to only use the results from the Scopus database. It was considered that future studies could make use of similar databases, such as WoS, Google Scholar, or Latindex.

The third phase of the search was to adjust the search criteria to eliminate articles that were unrelated to the topic under investigation (the majority of which dealt with the knowledge area of paleontology). This final filter resulted in 78 documents that were deemed sufficient to continue with the analysis. The results were then exported to various data formats, which were later processed and analyzed.

Several bibliometric indicators were used to measure the intensity or quality of the publications analyzed, with the following outputs being the most significant: number of articles, number of citations per article, average number of citations per article, and h-index rate [34]. Finally, this study also includes an index of articles and citation by population and the journal impact index, Scimago Journal Ranking (SJR).

\section{Results}

This research has been structured by analyzing the results in the following sections: evolution of the historic volume of publications, the most influential authors and cited references, most prolific countries, most relevant journals, most cited articles, most important institutions and funding organizations, areas of knowledge implied on this topic, and research trends in the field of local development.

\subsection{Evolution of the Number of Publications per Year}

Two distinct periods, separated by the beginning of the 21st century, clearly stand out with regards to the evolution of Ibero-American scientific articles on local development and as can be seen in Figure 2, t. Few articles (12) were found in the period between 1996 and 2000 nor was there a significant impact found for the related articles. This could be since it is precisely from 2000 when new journals that were focused on this subject are registered in the Scopus database. In addition, there is greater interest in local development by Ibero-American researchers since 2000, probably also due to the objectives of the United Nations Millennium Development Goals (MDGs) established in that year. The first article to appear in the database was published in 1986 and it focused on the transformation resulting from an agricultural development program in the Grande Carajás region and whether or not it contributed to local sustainability.

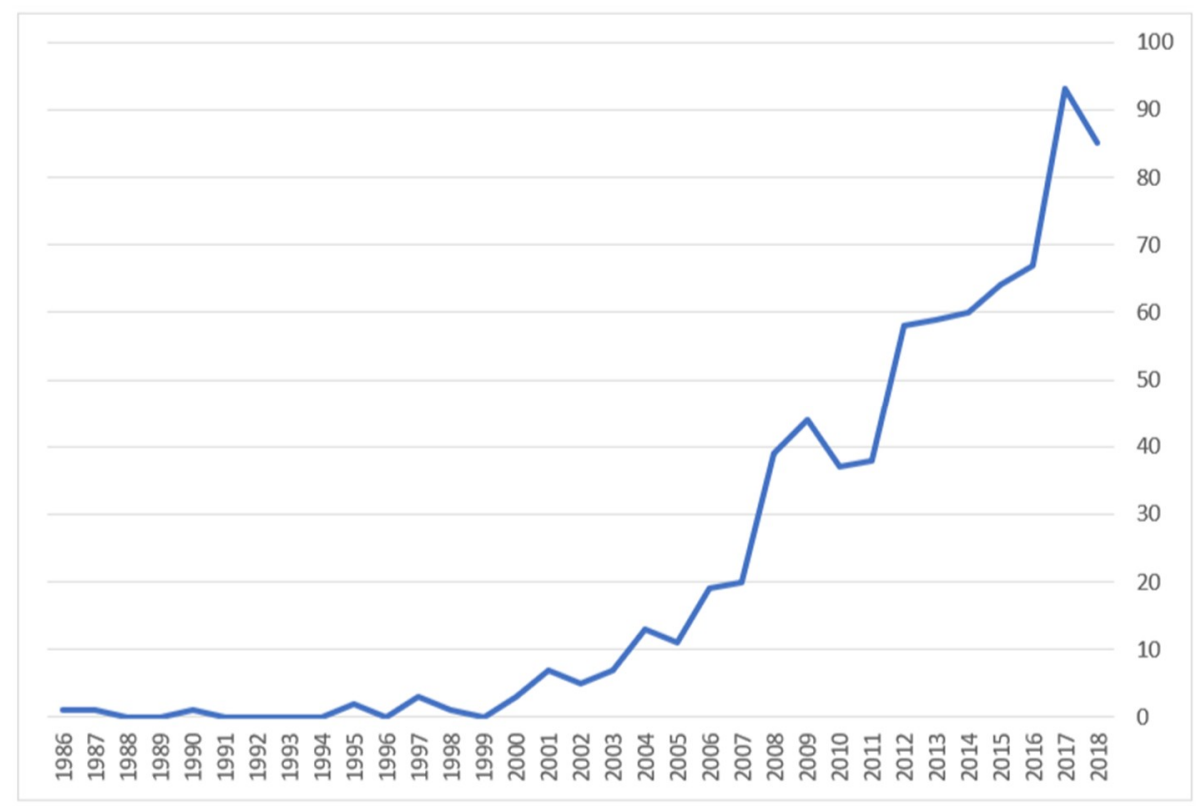

Figure 2. Annual evolution in the number of articles. 
At the beginning of the 21st century, the number of articles by Ibero-American authors that were related to the concept of local development grew, with eight of those articles attaining more than 50 citations (Table 1). Although the number of citations should be measured in the long term, or at least with enough time to allow for one research to serve as a base or influence another, a constant and steady level of citations can be appreciated (Figure 3).

Table 1. Structure of annual citations.

\begin{tabular}{|c|c|c|c|c|c|c|c|c|c|}
\hline YEAR & A & C & $\geq 50$ & $\geq 25$ & $\geq 10$ & $\geq 5$ & $\geq 1$ & $\mathrm{C} / \mathrm{A}$ & $\mathbf{h}$ \\
\hline 2018 & 85 & 26 & 0 & 0 & 0 & 0 & 17 & 0.31 & 3 \\
\hline 2017 & 93 & 120 & 0 & 0 & 1 & 9 & 39 & 1.29 & 5 \\
\hline 2016 & 67 & 226 & 1 & 1 & 6 & 11 & 36 & 3.37 & 7 \\
\hline 2015 & 64 & 167 & 0 & 0 & 5 & 10 & 38 & 2.61 & 7 \\
\hline 2014 & 60 & 217 & 1 & 2 & 5 & 11 & 33 & 3.62 & 6 \\
\hline 2013 & 59 & 211 & 0 & 1 & 7 & 13 & 45 & 3.58 & 8 \\
\hline 2012 & 58 & 339 & 0 & 4 & 10 & 19 & 37 & 5.84 & 10 \\
\hline 2011 & 38 & 176 & 0 & 1 & 6 & 10 & 30 & 4.63 & 7 \\
\hline 2010 & 37 & 258 & 1 & 3 & 8 & 11 & 28 & 6.97 & 9 \\
\hline 2009 & 44 & 361 & 0 & 5 & 10 & 18 & 32 & 8.20 & 10 \\
\hline 2008 & 39 & 317 & 1 & 4 & 10 & 17 & 31 & 8.13 & 10 \\
\hline 2007 & 20 & 117 & 0 & 1 & 5 & 7 & 13 & 5.85 & 5 \\
\hline 2006 & 19 & 179 & 0 & 4 & 8 & 9 & 14 & 9.42 & 8 \\
\hline 2005 & 11 & 140 & 1 & 1 & 5 & 6 & 10 & 14.00 & 5 \\
\hline 2004 & 13 & 277 & 1 & 3 & 6 & 7 & 10 & 21.31 & 6 \\
\hline 2003 & 7 & 270 & 3 & 3 & 3 & 3 & 6 & 38.57 & 4 \\
\hline 2002 & 5 & 33 & 0 & 1 & 1 & 1 & 3 & 6.60 & 1 \\
\hline 2001 & 7 & 184 & 2 & 2 & 3 & 3 & 6 & 26.29 & 3 \\
\hline 2000 & 3 & 38 & 0 & 1 & 1 & 3 & 3 & 12.67 & 3 \\
\hline 1999 & 0 & 0 & 0 & 0 & 0 & 0 & 0 & 0.00 & 0 \\
\hline 1998 & 1 & 1 & 0 & 0 & 0 & 0 & 1 & 1.00 & 1 \\
\hline 1997 & 3 & 7 & 0 & 0 & 0 & 0 & 2 & 2.33 & 2 \\
\hline 1996 & 0 & 0 & 0 & 0 & 0 & 0 & 0 & 0.00 & 0 \\
\hline 1995 & 2 & 25 & 0 & 0 & 2 & 2 & 2 & 12.50 & 2 \\
\hline 1994 & 0 & 0 & 0 & 0 & 0 & 0 & 0 & 0.00 & 0 \\
\hline 1993 & 0 & 0 & 0 & 0 & 0 & 0 & 0 & 0.00 & 0 \\
\hline 1992 & 0 & 0 & 0 & 0 & 0 & 0 & 0 & 0.00 & 0 \\
\hline 1991 & 0 & 0 & 0 & 0 & 0 & 0 & 0 & 0.00 & 0 \\
\hline 1990 & 1 & 10 & 0 & 0 & 1 & 1 & 1 & 10.00 & 1 \\
\hline 1989 & 0 & 0 & 0 & 0 & 0 & 0 & 0 & 0.00 & 0 \\
\hline 1988 & 0 & 0 & 0 & 0 & 0 & 0 & 0 & 0.00 & 0 \\
\hline 1987 & 1 & 7 & 0 & 0 & 0 & 1 & 1 & 7.00 & 0 \\
\hline 1986 & 1 & 20 & 0 & 0 & 1 & 1 & 1 & 20.00 & 1 \\
\hline Total & 738 & 3731 & 11 & 37 & 104 & 174 & 440 & 5.05 & 30 \\
\hline
\end{tabular}

A: the annual number of articles; $\mathrm{C}$ : the annual number of citations in total articles; $\mathrm{C} / \mathrm{A}$ : annual number of citations by article; h: Hirsch index.

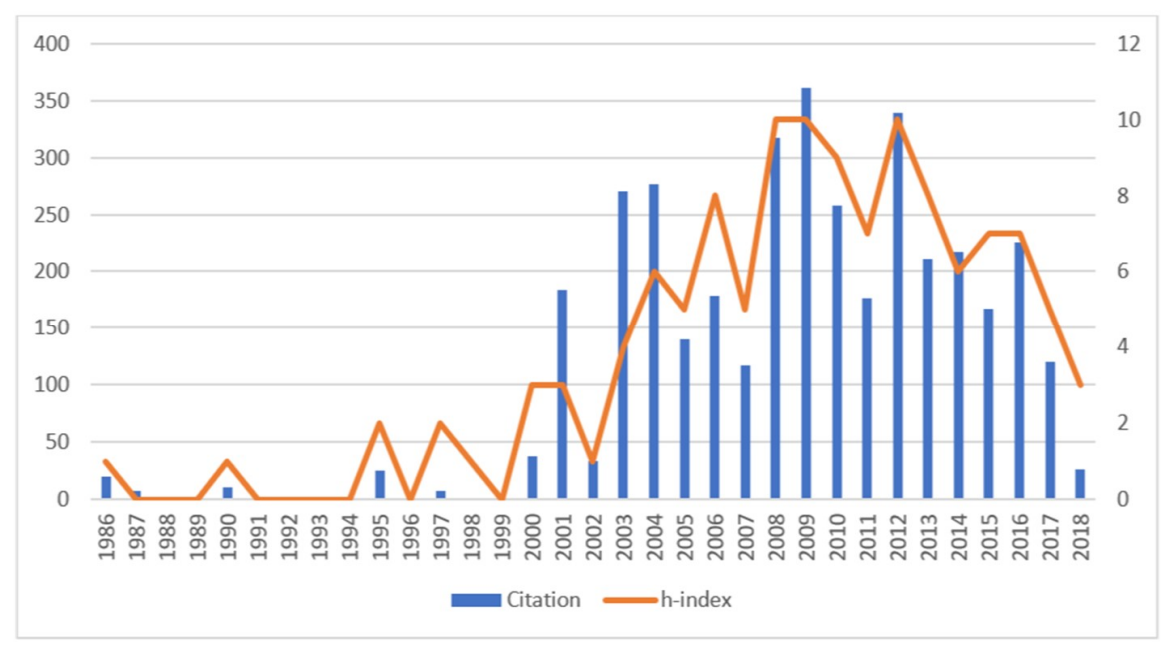

Figure 3. Annual evolution in the number of citations and h-index. 


\subsection{Most Relevant Authors}

Different parameters must be considered in order to understand who the most relevant authors are on a stated topic. The number of articles published discloses who are the most prolific and which authors have focused their careers on this line of research (Table 2). In this study, Professor Antoni Francesc Tulla of the Autonomous University of Barcelona leads the ranking with eight articles, which is double the number of the following six authors in the ranking. His research fundamentally focuses on rural development.

Table 2. The most influential authors.

\begin{tabular}{|c|c|c|c|c|c|c|c|c|}
\hline Author & University & Country & A & $\mathrm{C}$ & h & C/A & First Art & Last Art \\
\hline Aroca, P. & Universidad Adolfo Ibañez & Chile & 4 & 37 & 2 & 9.25 & 2008 & 2016 \\
\hline Fernández, G. & Universidad Del Zulia & Venezuela & 4 & 9 & 2 & 2.25 & 2008 & 2018 \\
\hline Narváez, M. & Universidad Del Zulia & Venezuela & 4 & 9 & 2 & 2.25 & 2008 & 2018 \\
\hline Palomares, R.C. & Universidad de Valencia & Spain & 4 & 2 & 1 & 0.50 & 2009 & 2017 \\
\hline
\end{tabular}

A: the annual number of articles; C: the annual number of citations in total articles; h: Hirsch index; C/A: annual number of citations by article; First art: Year first article published. Last art: Year last article published.

Professor Patricio Aroca from the Universidad Adolfo Ibáñez in Santiago de Chile leads this ranking when considering the number of citations per article, which is largely due to his studies in regional displacement in the Antofogasta region of Chile [35]. Finally, when analyzing the journal with the greatest number of citations [36], Professor Yves Cabannes from the Gestion Urbana Program in Quito, Ecuador, and affiliated with University College in London has garnered the greatest attention.

\subsection{Scientific Production by Country}

The two most significant countries publishing on the topic of local development are Spain and Brazil, both with over 200 documents (Table 3). Costa Rica, with three documents and 59 citations follows in the ranking, closely followed by Peru if the number of citations is taken into consideration.

Table 3. Articles and citation structure per country.

\begin{tabular}{rccccccccccc}
\hline $\mathbf{R}$ & Country & $\mathbf{A}$ & $\mathbf{C}$ & $\mathbf{h}$ & $\mathbf{C / A}$ & $\mathbf{2} \mathbf{2 5}$ & $\mathbf{\geq 1 0}$ & $\mathbf{\geq 5}$ & $\mathbf{2 1}$ & $\mathbf{A} /$ Pop & C/Pop \\
\hline 1 & Spain & 258 & 1724 & 21 & 6.68 & 18 & 50 & 79 & 172 & 5.49 & 36.68 \\
2 & Brazil & 213 & 659 & 12 & 3.09 & 6 & 17 & 36 & 108 & 1.01 & 3.14 \\
3 & Portugal & 71 & 575 & 12 & 8.10 & 6 & 16 & 26 & 55 & 7.10 & 57.50 \\
4 & Mexico & 68 & 206 & 7 & 3.03 & 2 & 6 & 11 & 36 & 0.54 & 1.62 \\
5 & Argentina & 43 & 191 & 7 & 4.44 & 2 & 5 & 12 & 23 & 0.96 & 4.24 \\
6 & Chile & 39 & 140 & 6 & 3.59 & 2 & 4 & 8 & 22 & 2.05 & 7.37 \\
7 & Venezuela & 29 & 37 & 4 & 1.28 & 0 & 0 & 2 & 19 & 0.91 & 1.16 \\
8 & Colombia & 28 & 110 & 5 & 3.93 & 1 & 4 & 6 & 15 & 0.61 & 2.39 \\
9 & Ecuador & 20 & 182 & 2 & 9.10 & 1 & 1 & 2 & 6 & 1.18 & 10.71 \\
10 & Cuba & 10 & 13 & 2 & 1.30 & 0 & 0 & 2 & 3 & 0.91 & 1.18 \\
11 & Peru & 8 & 141 & 4 & 17.63 & 1 & 4 & 4 & 7 & 0.25 & 4.41 \\
12 & Uruguay & 4 & 9 & 2 & 2.25 & 0 & 0 & 1 & 3 & 1.00 & 2.25 \\
13 & Costa Rica & 3 & 59 & 2 & 19.67 & 1 & 1 & 1 & 2 & 0.6 & 11.8 \\
14 & El Salvador & 3 & 21 & 2 & 7.00 & 1 & 1 & 2 & 3 & 0.43 & 3.00 \\
15 & Bolivia & 3 & 7 & 2 & 2.33 & 0 & 0 & 1 & 2 & 0.27 & 0.64 \\
16 & Andorra & 2 & 29 & 2 & 14.50 & 0 & 1 & 2 & 2 & 25.00 & 362.50 \\
17 & Nicaragua & 2 & 1 & 1 & 0.50 & 0 & 0 & 0 & 1 & 0.29 & 0.14 \\
18 & Dominican Republic & 1 & 1 & 1 & 1.00 & 0 & 0 & 0 & 1 & 0.10 & 0.10 \\
19 & Panama & 1 & 0 & 0 & 0.00 & 0 & 0 & 0 & 0 & 0.25 & 0.00 \\
\hline
\end{tabular}

A: the annual number of articles; C: annual number of citations in total articles; h: Hirsch index; C/A: annual number of citations by article. First art: Year first article published. Last art: Year last published; A/Pop: Articles per million population; C/Pop: Citations per million population. 
Andorra also stands out for the number of articles published, the number of citations per article, as well as the average number of citations per article. The Sustainability Observatory of Andorra has participated in projects that study the impact that the ski industry can have on the economy and the development of local areas in the mountainous regions of Andorra [37,38].

Of the 22 Ibero-American countries (Figure 4), only two do not make any tangible contribution: Guatemala and Paraguay, which confirmed the fact that the vast majority of Ibero-American countries are engaged with the topic of local development.

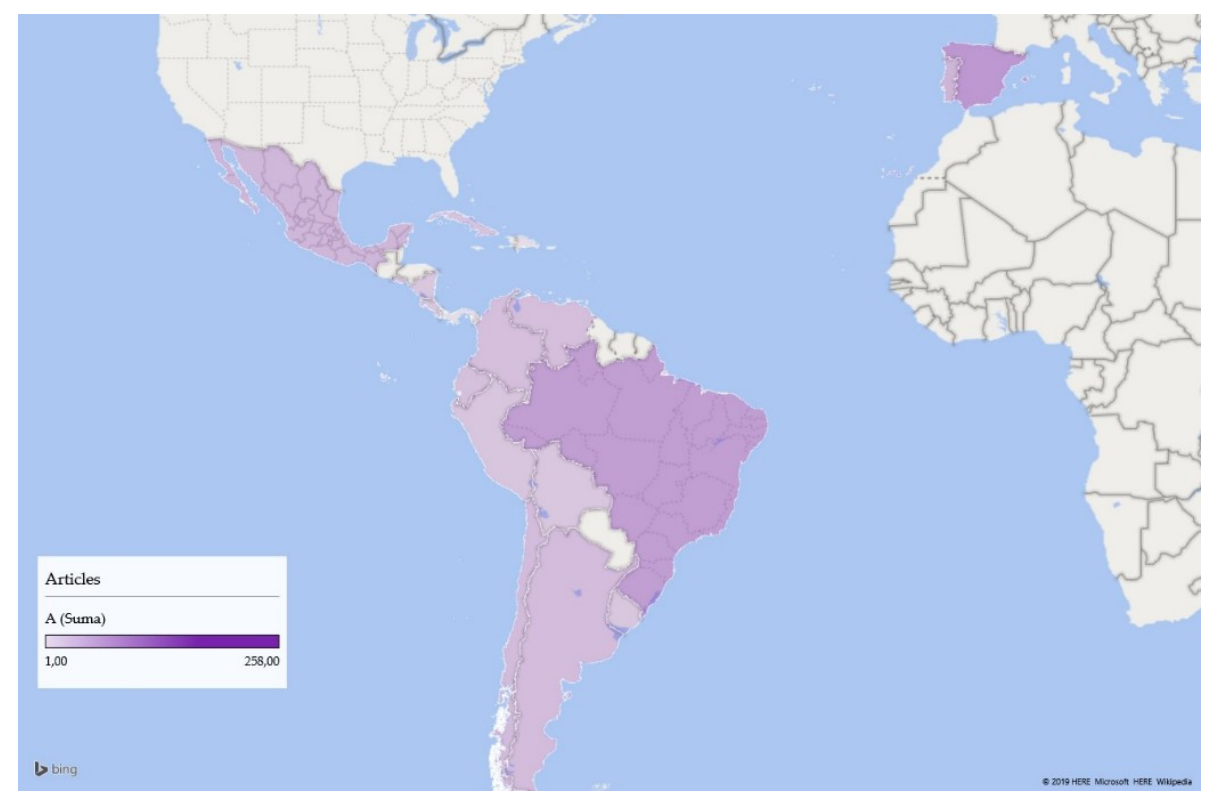

Figure 4. Ibero-American countries and volume of articles published.

Other notable aspects to take into account are the collaborations between Ibero-American countries and other nations (Figure 5). The United States and the United Kingdom, although presenting a limited volume of production, have collaborated with a large number of Ibero-American countries. Understandably, Portugal has close ties with Angola and Mozambique. Meanwhile, Spain shows strong links with Italy and Chile.

In conclusion, the relationships between Ibero-American countries were also analyzed (Figure 6) with the following results: Spain is the country with the highest number of links to other countries (13) and with exclusive relationships with two of them, Andorra and Peru. Brazil has strong links with Portugal, Mexico, and Argentina, and an exclusive link with Panama. El Salvador has collaborated with ten countries in its research, despite only publishing three articles.

\subsection{Most Influential Journals}

Revista Espacios (Venezuela) is the Ibero-American journal with the largest number of articles published on local development (35). Revista Espacios digital is a peer-reviewed publication, which is dedicated to disseminating studies and research, both in Spanish, English, and Portuguese, in the areas of production engineering, politics, and management of science and technology, innovation, technology management, education, and its related areas. It has a special interest in matters that are related to local development, from different perspectives. The next ranked journal based on the number of articles on local development (Table 4) is Revista Brasileira de Gestão e Desenvolvimento Regional (GEDR) (30 articles). This is a journal with a pluralist orientation that publishes theoretical and empirical contributions that are related to regional development, and enhances the interdisciplinary dialogue promoting different areas of contributions, such as health, engineering, architecture, psychology, history, or environmental science. The articles may be written in Portuguese, English, or Spanish. 


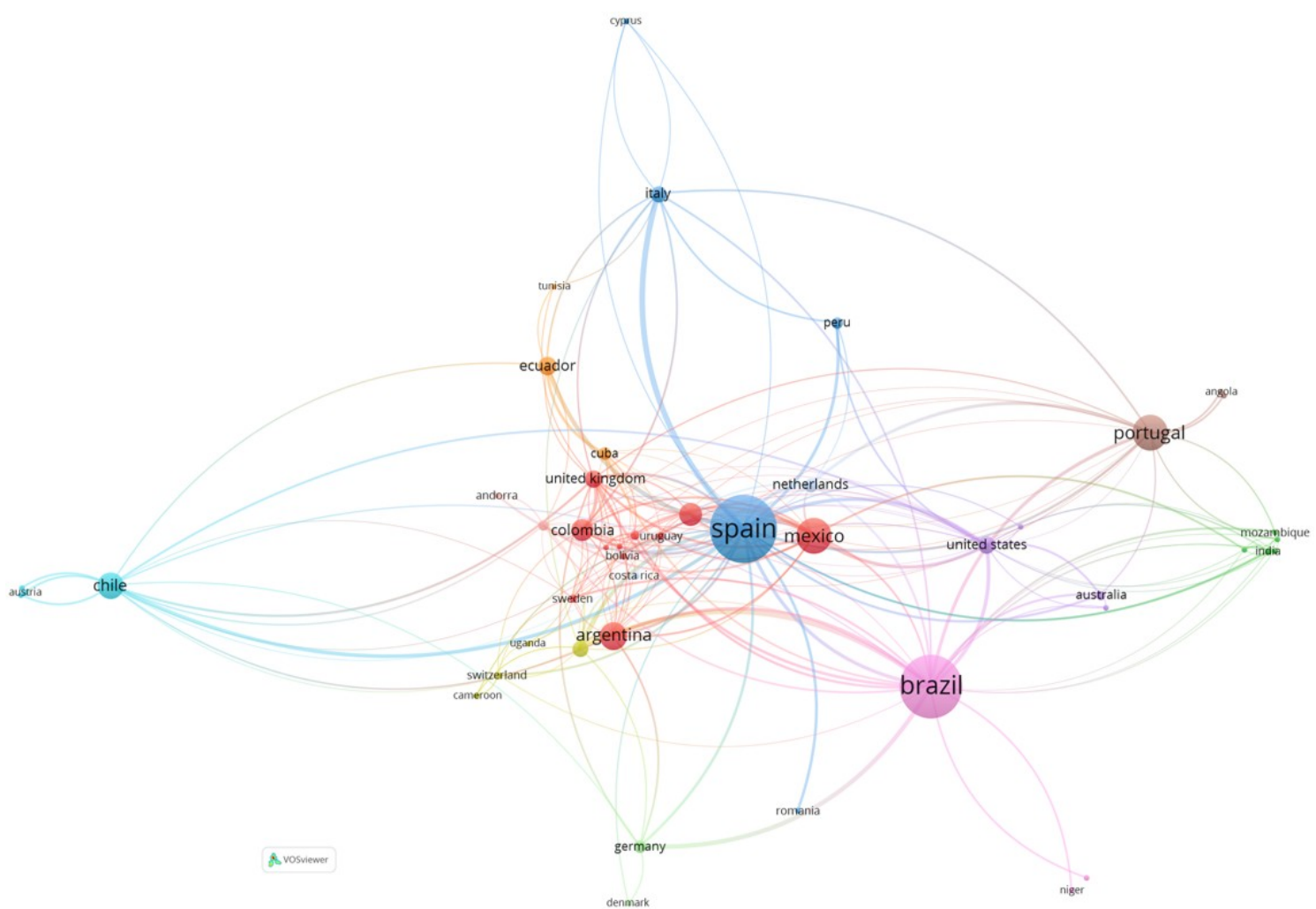

Figure 5. Co-citation Ibero-American-Rest of the World.

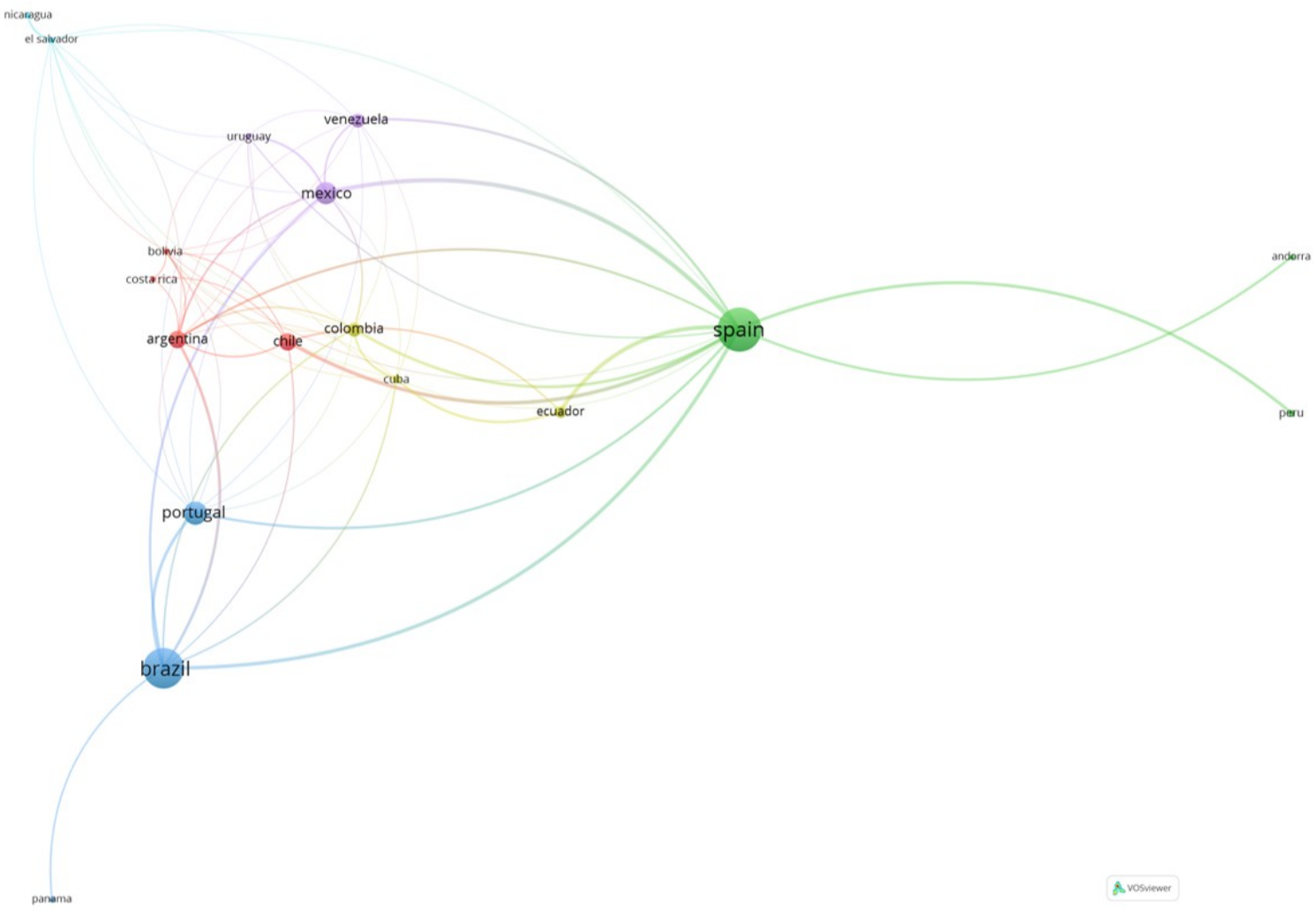

Figure 6. Co-citation among Ibero-American countries. 
Table 4. Most influential journals.

\begin{tabular}{ccccccc}
\hline $\mathbf{R}$ & Journal & A & C & C/A & h & R. Scimago \\
\hline 1 & Espacios & 35 & 4 & 0.11 & 1 & 0.16 \\
2 & Revista Brasileira de Gestão e Desenvolvimento Regional & 30 & 6 & 0.20 & 1 & 0.16 \\
3 & EURE & 28 & 131 & 4.68 & 6 & 0.45 \\
4 & Boletín de la Asociación de Geógrafos Españoles & 13 & 54 & 4.15 & 3 & 0.26 \\
5 & Cuadernos de Turismo & 11 & 17 & 1.55 & 2 & 0.16 \\
6 & Estudios Geográficos & 11 & 26 & 2.36 & 3 & 0.18 \\
7 & Revista de Administraçao Pública & 11 & 15 & 1.36 & 3 & 0.27 \\
8 & Documents d'Anàlisi Geogràfica & 10 & 20 & 2.00 & 4 & 0.21 \\
9 & Cuadernos Geográficos & 9 & 29 & 3.22 & 3 & 0.26 \\
10 & Investigaciones Geográficas & 9 & 21 & 2.33 & 3 & 0.23 \\
11 & Revista Venezolana de Gerencia & 9 & 6 & 0.67 & 1 & 0.21 \\
12 & Investigaciones Regionales & 9 & 39 & 4.33 & 4 & 0.26 \\
\hline
\end{tabular}

R: Ranking; A: total number of articles; C: number of citations in total articles; C/A: annual number of citations by article; h: Hirsch index; R. Scimago: ranking in Scimago (Scopus).

However, it is the journal EURE (Revista Latinoamericana de Estudios Urbanos Regionales—Latin American Journal of Regional Urban Studies), with 28 articles on this topic, which leads the other rankings: total citations (131), average citations per article (4.68), h-index (6), and ranking in Scimago (0.45). EURE is a Chilean quarterly publication that is specialized in the organization and territorial management of its urban, regional, and local expressions, with consideration for environmental issues. This journal publishes in Spanish and Portuguese. Boletín de la Asociación de Geógrafos Españoles (BAGE) (54 citations; average of 4.15) is another prominent journal, according to the number of citations and average citations per article. It is a peer-reviewed open access journal, which is published quarterly online, including miscellaneous and special issues, with papers in Spanish and English. The journal aims to promote the advancement of the field of Geography at the national and international level by publishing research that was done by geographers, but also by other social and environmental scientists that are interested in territorial processes at any scale. Investigaciones Regionales-Journal of Regional Research (39 citations; average of 4.33) is also relevant. It main objective is disseminating quality works in the broad academic and professional field of regional, urban, and territorial studies, published in both Spanish and English. This Spanish journal has a multidisciplinary approach, publishing research from different fields, such as Economics, Geography, Sociology, Land Planning, and Political Science.

Finally, in relation to the h-index, other relevant journals are: Documents d'Anàlisi Geogràfica (4) and Investigaciones Regionales (4). The first is an open-access academic journal that was aimed at scholars and professionals who have an interest in the interactions between nature, society, politics, economy, and culture.

\subsection{Most Cited Articles}

Articles with a high number of citations belong to different areas of knowledge due to the transversal nature of local development, and also address very different topics, although with the issue of local development as a central theme. The most cited article (Table 5) is "Participatory budgeting: A significant contribution to participatory democracy" (Cabanes, 2004) [36] (170 citations), published in Environment and Urbanization. This paper describes participatory budgeting in Brazil and elsewhere as a significant area of innovation in democracy and local development, providing a systematic analysis of the range of experience that can be included in participatory budgeting.

"International Capital versus Local Population: The Environmental Conflict of the Tambogrande Mining Project, Peru" is the next article in this ranking (Roldan Muradian, Martinez-Alier, and Correa, 2003) [39] (87 citations). It analyzes a social clash over a gold mining project, which is characterized in terms of perception of environmental risks, preferred decision-making mechanisms, trust in experts and government institutions, and fairness in the distribution of burdens and benefits. The results 
revealed that $85 \%$ of the local population was against the project, mainly because of the lack of a participatory procedure for deciding local development strategies.

Table 5. Articles with the highest number of citations.

\begin{tabular}{clc}
\hline $\mathbf{R}$ & \multicolumn{1}{c}{ Article Title } & $\mathbf{C}$ \\
\hline 1 & Participatory budgeting: A significant contribution to participatory democracy & 170 \\
2 & Int. capital versus local population: The environmental conflict of the Tambogrande Mining Project, Peru & 87 \\
3 & Socio-cultural val. of ecos. serv: Uncovering links between values, drivers of change, and human well-being & 78 \\
4 & Incentive regulation and efficiency of Portuguese Port authorities & 76 \\
5 & Social innovation research: An emerging area of innovation studies? & 75 \\
\hline
\end{tabular}

C: total number of citations.

Iniesta-Arandia et al. (2014) [40] in "Socio-cultural valuation of ecosystem services: Uncovering the links between values, drivers of change, and human well-being" (78 citations), published in Ecological Economics, presents results from an analysis of stakeholders' perceptions of ecosystem services, well-being, and drivers of change in two semi-arid watersheds in south-eastern Spain. The identified five stakeholder groups, including: locals dependent on provisioning ecosystem services, locals not directly dependent on provisioning ecosystem services, environmental and local development professionals, and rural and nature tourists.

The fourth most cited article is "Incentive regulation and efficiency of Portuguese Port authorities" (Pestana Barros, 2003) [41] (76 citations), published in Maritime Economics \& Logistics. The authors analyze the technical and allocative efficiencies of Portuguese seaport authorities in order to investigate whether the state's policy is achieving its aims, proposing a policy revision to enforce efficiency, based on a governance environment framework.

The fifth article in this ranking is "Social innovation research: An emerging area of innovation studies?" by Van der Have and Rubalcaba (2016) [42] (75 citations), published in Research Policy. This paper traces the content, scope and history of modern social innovation research across disciplines by applying network and bibliometric analyses. It suggests that local development is one of the communities implied in social innovation field, as well as that the interest of social innovation in the areas of management and entrepreneurship is very recent.

\subsection{Most Relevant Institutions Promoting Research}

Universities are the main Ibero-American organizations that promote publications regarding local development (Table 6). Spanish universities stand out, with four ranked in the top ten. Brazil is also relevant, with two universities in this ranking. Universidad Autónoma de Barcelona (Spain) and Universidade de São Paulo (Brazil) are the main entities in terms of the volume of publications, with 34 articles each.

Table 6. Most relevant institutions promoting research.

\begin{tabular}{|c|c|c|c|c|c|c|c|c|c|c|}
\hline $\mathbf{R}$ & University & Country & A & $\mathrm{C}$ & $\mathbf{h}$ & C/A & $\geq 25$ & $\geq 10$ & $\geq 5$ & $\geq 1$ \\
\hline 1 & Universidad Autónoma de Barcelona & Spain & 34 & 336 & 8 & 9.88 & 5 & 8 & 15 & 24 \\
\hline 2 & Universidade de Sao Paulo & Brazil & 34 & 85 & 5 & 2.50 & 0 & 2 & 7 & 22 \\
\hline 3 & Universidad de Valencia & Spain & 22 & 68 & 5 & 3.09 & 0 & 3 & 5 & 12 \\
\hline 4 & $\begin{array}{c}\text { Consejo Nacional Investigaciones } \\
\text { Científicas y Técnicas }\end{array}$ & Argentina & 19 & 127 & 5 & 6.68 & 2 & 4 & 5 & 9 \\
\hline 5 & Universidad Del Zulia & Venezuela & 18 & 21 & 3 & 1.17 & 0 & 0 & 1 & 11 \\
\hline 6 & Universidad Nacional Autónoma de Mexico & Mexico & 17 & 124 & 6 & 7.29 & 2 & 5 & 7 & 9 \\
\hline 7 & Universidade de Lisboa & Portugal & 16 & 224 & 7 & 14.00 & 3 & 6 & 8 & 12 \\
\hline 8 & Universidade Estadual de Campias & Brazil & 15 & 129 & 5 & 8.60 & 3 & 4 & 5 & 11 \\
\hline 9 & Universidad Autónoma de Madrid & Spain & 14 & 200 & 7 & 14.29 & 2 & 6 & 9 & 10 \\
\hline 10 & Universidad de Santiago de Compostela & Spain & 13 & 61 & 4 & 4.69 & 1 & 2 & 4 & 8 \\
\hline
\end{tabular}

R: Ranking; A: total number of articles; C: total number of citations; h: Hirsch index; C/A: total number of citations per article. 
Universidad Autónoma de Barcelona (UAB) has various Institutes and Research Centers that also work on local development, such as the Center for the Study of Organizations and Decisions in Economics (CODE) or the Institute for Government and Public Policy (IGOP). UAB also has several specialized courses, such as a Postgraduate in Social and Solidarity Economy: Local Development, Cooperatives and Social Transformation; Public Policies and Local Development; or, Introduction to local economic development. Universidade de São Paulo (USP) is the major institution of higher learning and research in Brazil, being currently responsible for more than $20 \%$ of all scientific production in Brazil. The third organization in this top ten is the Universidad de Valencia in Spain (22 articles). This university has an Institute for Local Development, which is a research center on the theory and practice of local development in its broadest sense, with experts in different dimensions of sustainable development and development strategies at the local level.

With reference to the h-index, the most relevant universities are: Universidad Autónoma de Barcelona (8), Universidade de Lisboa (7), and Universidad Autónoma de Madrid (7), which offer a Master's Degree in Planning and Sustainable Territorial Development.

As for the number of citations, once again it is Universidad Autónoma de Barcelona, which leads the top ten (336 citations), followed by the Universidade de Lisboa (224), and Universidad Autónoma de Madrid (200), which also enjoys a better average of citations per article (14.29).

Among the most relevant organizations in terms of publications on local development the Consejo Nacional de Investigaciones Científicas y Técnicas de Argentina (CONICET)-National Council of Scientific and Technical Research of Argentina is noteworthy. CONICET structures its support for research and development around projects. 17\% of the Centers and Institutes of the Council have projects in the area of Social Sciences and Humanities, offering a wide range of disciplines, including: History, Geography, Social and Cultural Anthropology; Sociology, Social Communication and Demography; and, Economics, Management Sciences, and Public Administration.

\subsection{Funding Organizations}

Four of the ten main Ibero-American entities financing research related to local development are from Brazil (Table 7): Conselho Nacional de Desenvolvimento Científico e Tecnológico (CNPq) (11 articles); Fundação de Amparo à Pesquisa do Estado de São Paulo (6 articles); Coordenação de Aperfeiçoamento de Pessoal de Nivel Superior (three articles); and, Financiadora de Estudos e Projetos (three articles).

Table 7. Funding organizations sponsoring research.

\begin{tabular}{clcc}
\hline $\mathbf{R}$ & \multicolumn{1}{c}{ Sponsor } & Country & A \\
\hline 1 & Conselho Nacional de Desenvolvimento Científico e Tecnológico (CNPq) & Brazil & 11 \\
2 & Fundação de Amparo à Pesquisa do Estado de São Paulo & Brazil & 6 \\
3 & Fundação para a Ciência e a Tecnologia & Portugal & 4 \\
4 & Consejo Nacional de Investigaciones Científicas y Técnicas & Argentina & 3 \\
5 & Coordenação de Aperfeiçoamento de Pessoal de Nível Superior & Brazil & 3 \\
6 & European Commission & Spain/Portugal & 3 \\
7 & Financiadora de Estudos e Projetos & Brazil & 3 \\
8 & Ministerio de Ciencia e Innovación (MICINN) & Spain & 3 \\
9 & Comisión Nacional de Investigación Científica y Tecnológica (CONICYT) & Chile & 2 \\
10 & Consejo Nacional de Ciencia y Tecnología & Mexico & 2 \\
\hline
\end{tabular}

A: total number of articles.

Conselho Nacional de Desenvolvimento Científico e Tecnológico (CNPq) is an agency of the Brazilian Ministry of Science, Technology, Innovations, and Communications. Its main objective is the promotion of the scientific and technological investigation of Brazilian researchers, as well as participating in the formulation of its policies, contributing to sustainable development. Fundação de Amparo à Pesquisa do Estado de São Paulo (FAPESP) (São Paulo Research Foundation) aims to provide scholarships, funds, and programs to support research, education, and innovation, in public and private institutions and 
companies in the State of São Paulo. Coordenação de Aperfeiçoamento de Pessoal de Nível Superior (CAPES) is a Brazilian federal government agency under the Ministry of Education, which is responsible for coordinating the improvement of Higher Education personnel, as well as providing quality assurance in undergraduate and postgraduate institutions in Brazil. Financiadora de Estudos e Projetos (FINEP) (Funding Authority for Studies and Projects) is an organization of the Brazilian federal government under the Ministry of Science of Technology, which is devoted to funding science and technology in the country.

There are also entities from Portugal, Argentina, Spain, Chile, Mexico, and the European Union in this ranking (European Commission). Community-led local development (CLLD) is a term used by the European Commission to describe an approach that turns traditional "top down" development policy on its head. Under CLLD, local people form a local partnership that designs and implements an integrated development strategy (European Commission Website) [43]. This local partnership receives long-term funding from European Funds. Community Initiatives, such as LEADER, URBAN, or EQUAL, which the Structural and the Rural Development Funds finance, focus on specific sub-regional areas and take into account local needs and potential, which promotes design and implementation of local development strategies.

\subsection{Main Areas of Knowledge}

As previously mentioned, local development is a very transversal topic, which has been approached from very different perspectives. This means that there are many areas of knowledge involved in research on local development, such as: Social Science, Environmental topics, Business, Economics, Finance, Agricultural and Biological Science, Arts and Humanities, Engineering, Medicine, Computer Science, Psychology, or Health professions (Table 8). Some works even include several areas of knowledge, due to the topics investigated.

Table 8. Main areas of knowledge regarding local development.

\begin{tabular}{ccc}
\hline Area of Knowledge & Articles & \% T \\
\hline Social Science & 485 & 65.72 \\
Environmental Science & 150 & 20.33 \\
Business, Management and Accounting & 125 & 16.94 \\
Economics, Econometrics and Finance & 108 & 14.63 \\
Earth and Planetary Sciences & 98 & 13.28 \\
Agricultural and Biological Science & 78 & 10.57 \\
Decision Sciences & 40 & 5.42 \\
Arts and Humanities & 39 & 5.28 \\
Engineering & 34 & 4.61 \\
Medicine & 30 & 4.07 \\
Energy & 21 & 2.85 \\
Computer Science & 10 & 1.36 \\
Psychology & 5 & 0.68 \\
Health Professions & 4 & 0.54 \\
\hline
\end{tabular}

$\% \mathrm{~T}$ : Percentage of articles with respect to the total published figure.

Social Science is the most prolific area of knowledge, with 485 articles, which represents $65.72 \%$ of the total. It is followed by Environmental Science (150 articles; 20.33\%), Business, Management and Accounting (125 articles; 16.94\%), and Economics, Econometrics and Finance (108 articles; 14.63\%), Earth and Planetary Sciences (98 articles; 13.28\%), and Agricultural and Biological Science (78 articles; 10.57\%).

Social Science includes works about topics including social capital; sustainable tourism development; entrepreneurship; or, the community development process. Environmental Science collects papers on culture; local institutional development; sustainable development; or, conservation and biodiversity. Business, Management and Accounting is about entrepreneurship and small business management; business incubators; human resource management; environmental management in local government; or, accounting. In the area of Economics, Econometrics, and Finance, research topics include small 
banks and local economic development; financial intermediation and economic growth; ecological economics; local economic development policies; economic growth; financial development; sources of growth; or, local and regional development partnerships. Topics on Earth and Planetary Sciences linking local development are about sustainability science; managing planet Earth; or, human development. In Agricultural and Biological Science. there are papers on agroecology; sustainable agriculture; or, advanced agricultural biotechnologies.

\subsection{Trends}

A wide variety of subjects and topics are found in the research on local development. A fractional counting method based on bibliographic data on co-occurrence on the authors' keywords was employed in order to comprehend the main trends. Of the 2085 keywords, the minimum of occurrences of a keyword was established at four with a resulting 84 keywords identified.

Figure 7 shows a trend map that identifies the most relevant topics and uses different colors to highlight the most commonly used authors' keywords since 2011. The most recent keywords are marked in yellow. Thus, the map highlights the main interactions between the most frequent terms in this research. Nowadays, academia is focused on topics, such as local development; social capital; tourism; sustainable development; entrepreneurship; public policies; governance; rural development; territory; innovation; regional and local development; rural tourism; Spain; Mexico; Brazil; employment; landscape; and, Portugal.

Finally, with reference to the trend map, the following are the most relevant subjects in research on local development: tourism; education; mining; geotourism; climate change; local sustainable development; social innovation; gender; creativity; social farming; and, traditional communities.

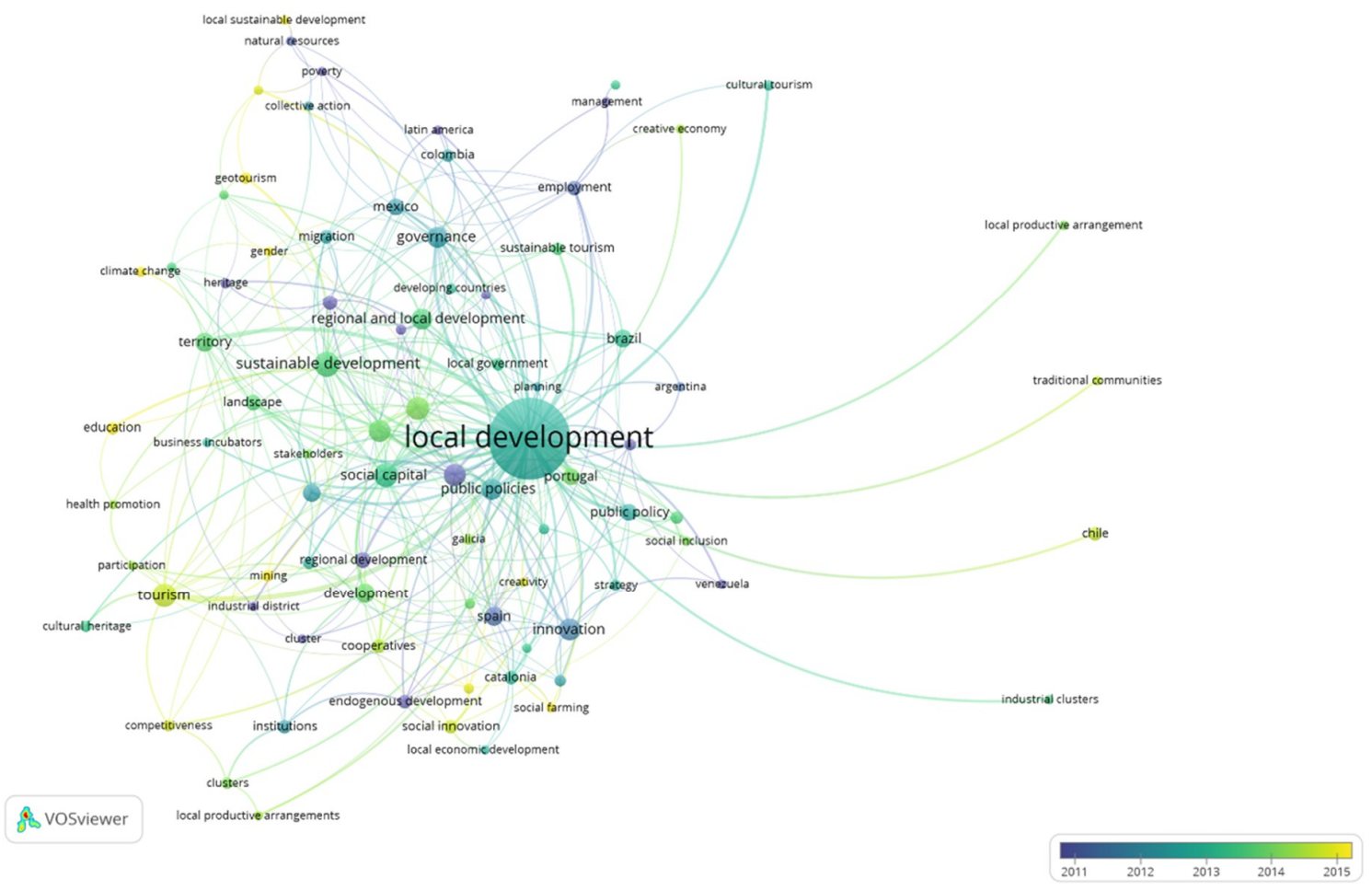

Figure 7. Trends map based on co-occurrence on authors' keywords, and evolution from 2011.

\section{Conclusions}

There is a consensus that sustainable development must be the basis for development based on the local initiative. Local development can only arise from the willingness and commitment on the part of the main political, social, and economic actors to intervene in the growth processes that take place in their territories, as well as the ability to identify and redirect their reconversion to the so-called "new economy". 
The process of profound globalization has transformed the concept and management of development, which has resulted in a strengthening of the responsibilities of local and regional administrations in their strategic planning and promotion. Although local development manifests itself in very diverse areas of management and in many fields, all of them address economic and social processes in one way or another.

When considering the evolution in the volume of publications on local development, it is observed that the first article is from 1986, although it is not until the arrival of the 21st century that the publications by Ibero-American authors on local development began to proliferate.

Regarding the most influential authors on this topic, Professor Tulla (Autonomous University of Barcelona, Spain) leads the number of publications with research primarily focused on rural development. Meanwhile, Professor Patricio Aroca (Adolfo Ibáñez University, Chile) has the highest average of citations per article.

The countries with the most outstanding scientific production in local development are Spain and Brazil. This field of research is of interest to most Ibero-American countries, according to the results of this bibliometric analysis. Regarding collaboration between Ibero-American countries and other nations, Portugal has Angola and Mozambique as natural partners, while Spain mainly collaborates with Italy and Chile. Spain is the country with the highest number of links with other Ibero-American countries, followed by Brazil, which has an intense relationship with Portugal, Mexico, and Argentina.

Revista Espacios (Venezuela) is the journal with the largest number of articles published on local development, followed by Revista Brasileira de Gestão e Desenvolvimento Regional. However, it is the Chilean journal EURE (Revista Latinoamericana de Estudios Urbanos Regionales) that leads the rankings in terms of citations, average citations per article, and h-index.

The most cited article is "Participatory budgeting: A significant contribution to participatory democracy" (Cabanes, 2004), published in Environment and Urbanization, followed by "International Capital Versus Local Population: The Environmental Conflict of the Tambogrande Mining Project, Peru" (Roldan Muradian, Martinez-Alier, and Correa, 2003), published in Society and Natural Resources.

Spanish universities lead the ranking of universities with the highest volume of publications on local development. This is followed by Brazil. With regards to the number of publications, Universidad Autónoma de Barcelona (Spain) and Universidade de São Paulo (Brazil) are the main entities. With regards to the h-index, Universidad Autónoma de Barcelona, Universidade de Lisboa, and Universidad Autónoma de Madrid are the most relevant universities. Four of the ten main Ibero-American entities financing research related to local development are from Brazil, with Conselho Nacional de Desenvolvimento Científico e Tecnológico (CNPq) and y Fundação de Amparo à Pesquisa do Estado de São Paulo being the most noteworthy

As local development is a transversal field, it has been studied from different perspectives. Thus, there are many areas of knowledge that are involved in this topic, such as social science, environmental topics, business, economics, finance, agricultural, etc. Social Science is the most prolific area of knowledge, representing $65.72 \%$ of the total.

Academia is currently focused on topics, such as local development, social capital, tourism, sustainable development, entrepreneurship, public policies, or rural tourism. Finally, this paper identified the most relevant subjects for researching local development. They are the following: tourism; education; mining; geotourism; climate change; local sustainable development; social innovation; gender; creativity; social farming; and, traditional communities. Therefore, a close relationship can be observed between local development and other aspects not only linked to the economic and social terrain, but also to the environmental one. The term local development is no longer understood as an isolated event, but it is linked to other environmental phenomena, such as climate change or sustainability. This even leads to triangulations, such as geotourism, subject in which different areas intervene and aims to understand the existence of new forms of progress.

This research is not exempt from several limitations, some of which are directly connected with the characteristics of the bibliometric analysis, a research method that is quantitative in nature. However, 
it is important to also provide a qualitative analysis in order to have a more comprehensive perspective of the research field under analysis, given that some authors may only publish a few articles, but be considered to be very influential in a specific subject. Thus, in this research, not only is the volume of articles published considered, but also the qualitative features and standardized metrics, such as the number of citations or the h-index. This notwithstanding, future research could include other quantitative or qualitative tools, as well implement a systematic literature review while using other tools, such as a meta-analysis.

Author Contributions: J.L.R.-R., J.U.-T., J.D.P.V. and J.R.P.M. have contributed in the same way to the writing of this manuscript, and all the authors have read and approved the final manuscript.

Funding: This research received no external funding.

Acknowledgments: This article was made during the research stay at the University of Beira Interior (Portugal), thanking them for the support and facilities they have given us during this period.

Conflicts of Interest: The authors declare no conflict of interest.

\section{References}

1. Uribe-Toril, J.; Pablo Valenciano, J.D. El desarrollo local y empresarial: La formación como factor básico para orientar al emprendedor. Intang. Cap. 2013, 9, 644-677.

2. Kondonassis, A.J.; Malliaris, A.G.; Okediji, T.O. Swings of the pendulum: A review of theory and practice in development economics. Am. Econ. 2000, 44, 17-23. [CrossRef]

3. Elizalde, A.; Hevia, A.E. Planificación Estratégica Territorial y Políticas Públicas para el Desarrollo Local; United Nations Publications: New York, NY, USA, 2003; p. 29.

4. Lira, I.S. Desarrollo económico local y competitividad territorial en América Latina. Rev. CEPAL 2000, 585, 81-100.

5. Moncayo, E. Evolución de los Paradigmas y Modelos Interpretativos del Desarrollo Territorial (No. 13); Naciones Unidas Comisión Económica para América Latina y el Caribe (CEPAL): Santiago, Chile, 2001.

6. Clark, C. The Morphology of Economic Growth. In The Conditions of Economic Progress; Macmillan: London, UK, 1940; pp. 337-373.

7. Fisher, A.G. Production, primary, secondary and tertiary. Econ. Rec. 1939, 15, 24-38. [CrossRef]

8. Perroux, F. Economic space: Theory and applications. Q. J. Econ. 1950, 64, 89-104. [CrossRef]

9. Juárez, S.M.; Villegas, J.B.H.; Méndez, J.A.P. La importancia del comercio internacional en Latinoamérica. Obs. Econ. Latinoam. 2014, 201, 1-16.

10. Krugman, P. Toward a counter-counterrevolution in development theory. World Bank Econ. Rev. 1992, 6, 15-38. [CrossRef]

11. Boisier, S. Bioregionalismo: Una ventana hacia el desarrollo territorial endógeno y sustentable. Rev. Desarro. Local 2015, 1, 42-66.

12. Garofoli, G. Virtuous and vicious circles: Lessons for current european policies from Italian post-war development. Eur. J. Comp. Econ. 2017, 14, 39.

13. Gutierrez, L. Sistema teórico explicativo sobre la dinámica de las redes interorganizacionales. Rev. Venez. Gerenc. 2017, 22, 97-120.

14. Schölin, T.; Ohlsson, H. The role of regions for different forms of business organizations. Entrep. Reg. Dev. 2017, 29, 197-214. [CrossRef]

15. Hoyng, R. The politics of skill and potential in an 'emerging'region: Upskilling initiatives in Istanbul. Eur. J. Cult. Stud. 2018, 21, 651-668. [CrossRef]

16. Sforzi, F. Repensar el distrito industrial: 35 años después. Investig. Reg. J. Reg. Res. 2015, 32, 11-29.

17. Ceresia, F.; Moreno, R.M.M.; Puchol, Á.S. The Perception and Attitudes Towards City Garbage Management: A First Analysis. Eur. J. Interdiscip. Stud. 2017, 3, 75-81. [CrossRef]

18. Banco Interamericano de Desarrollo. Protección Social para la Equidad y el Crecimiento; Banco Interamericano de Desarrollo: Washington, DC, USA, 2000.

19. Garfield, E. Citation Index for Science. A New Dimension in Documentation through Association of Ideas. Science 1955, 122, 108-111. [CrossRef] [PubMed] 
20. Claveau, F.; Gingras, Y. Macrodynamics of economics: A bibliometric history. Hist. Political Econ. 2016, 48, 551-592. [CrossRef]

21. Wang, M.H.; Li, J.; Ho, Y.S. Research articles published in water resources journals: A bibliometric analysis. Desalin. Water Treat. 2011, 28, 353-365. [CrossRef]

22. Hendrix, D. Tenure metrics: Bibliometric education and services for academic faculty. Med Ref. Serv. Q. 2010, 29, 183-189. [CrossRef]

23. Haba-Osca, J.; Gonzalez-Sala, F.; Osca-Lluch, J. Education Journals Worldwide: An Analysis of the Publications Included in the 2016 Journal Citation Reports (JCR); Ministry of Education and Vocational Training of Spain: Madrid, Spain, 2019.

24. Kalyane, V.L.; Sen, B.K. Annals of Library Science and Documentation 42.4. In A Bibliometric Study of the Journal of Oilseeds Research; NISCAIR-CSIR: New Delhi, India, 1995; pp. 121-141.

25. Uribe-Toril, J.; Ruiz-Real, J.L.; Haba-Osca, J.; De Pablo, J. Forests' First Decade: A Bibliometric Analysis Overview. Forests 2019, 10, 72. [CrossRef]

26. Clarke, A.; Gatineau, M.; Grimaud, O.; Royer-Devaux, S.; Wyn-Roberts, N.; Le Bis, I.; Lewison, G. A bibliometric overview of public health research in Europe. Eur. J. Public Health 2007, 17, 43-49. [CrossRef]

27. De Moya-Anegón, F.; Herrero-Solana, V. Science in America Latina: A comparison of bibliometric and scientific-technical indicators. Scientometrics 1999, 46, 299-320. [CrossRef]

28. Bornmann, L.; Wagner, C.; Leydesdorff, L. BRICS countries and scientific excellence: A bibliometric analysis of most frequently cited papers. J. Assoc. Inf. Sci. Technol. 2015, 66, 1507-1513. [CrossRef]

29. Archambault, É.; Campbell, D.; Gingras, Y.; Larivière, V. Comparing bibliometric statistics obtained from the Web of Science and Scopus. J. Am. Soc. Inf. Sci. Technol. 2009, 60, 1320-1326. [CrossRef]

30. Mongeon, P.; Paul-Hus, A. The journal coverage of Web of Science and Scopus: A comparative analysis. Scientometrics 2016, 106, 213-228. [CrossRef]

31. Van Eck, N.J.; Waltman, L. Software survey: VOSviewer, a computer program for bibliometric mapping. Scientometrics 2010, 84, 523-538. [CrossRef]

32. Leimkuhler, F.F. On Bibliometric Modeling; Elsevier: Amsterdam, The Netherland, 1988.

33. Osareh, F. Bibliometrics, citation analysis and co-citation analysis: A review of literature I. LIBRI 1996, 46, 149-158. [CrossRef]

34. Hirsch, J.E. An index to quantify an individual's scientific research output. Proc. Natl. Acad. Sci. USA 2005, 102, 16569-16572. [CrossRef]

35. Aroca, P.; Atienza, M. La conmutación regional en Chile y su impacto en la Región de Antofagasta. EURE 2008, 34, 97-120. [CrossRef]

36. Cabannes, Y. Participatory budgeting: A significant contribution to participatory democracy. Environ. Urban. 2004, 16, 27-46. [CrossRef]

37. Pons, M.; López-Moreno, J.I.; Rosas-Casals, M.; Jover, È. The vulnerability of Pyrenean ski resorts to climate-induced changes in the snowpack. Clim. Chang. 2015, 131, 591-605. [CrossRef]

38. Pons-Pons, M.; Johnson, P.A.; Rosas-Casals, M.; Sureda, B.; Jover, È. Modeling climate change effects on winter ski tourism in Andorra. Clim. Res. 2012, 54, 197-207. [CrossRef]

39. Roldan Muradian, R.; Martinez-Alier, J.; Correa, H. International Capital Versus Local Population: The Environmental Conflict of the Tambogrande Mining Project, Peru. Soc. Nat. Resour. 2003, 16, 775-792. [CrossRef]

40. Iniesta-Arandia, I.; Garcia-Llorente, M.; Aguilera, P.A.; Montes, C.; Martín-López, B. Socio-cultural valuation of ecosystem services: Uncovering the links between values, drivers of change, and human well-being. Ecol. Econ. 2014, 108, 36-48. [CrossRef]

41. Pestana Barros, C. Incentive regulation and efficiency of Portuguese Port authorities. Marit. Econ. Logist. 2003, 5, 55-69. [CrossRef]

42. Van der Have, R.; Rubalcaba, L. Social innovation research: An emerging area of innovation studies? Res. Policy 2016, 45, 1923-1935. [CrossRef]

43. European Commission Website. Available online: https://ec.europa.eu/regional_policy/en/information/ publications/brochures/2014/community-led-local-development (accessed on 15 June 2019).

(C) 2019 by the authors. Licensee MDPI, Basel, Switzerland. This article is an open access article distributed under the terms and conditions of the Creative Commons Attribution (CC BY) license (http://creativecommons.org/licenses/by/4.0/). 